\title{
ANALISIS KEPUASAN PASIEN RAWAT INAP DAN RAWAT JALAN DI RS MH. THAMRIN CILEUNGSI
}

\author{
Atikah Pustikasari ${ }^{1}$, Ilah Muhafilah ${ }^{2}$ \\ Program studi D3 Keperawatan Universitas MH.Thamrin \\ Program studi S1 Keperawatan Universitas MH.Thamrin \\ atikah.pustikasari@yahoo.com
}

\begin{abstract}
ABSTRAK
Kepuasan adalah perasaan senang atau kecewa seseorang yang timbul karena membandingkan kinerja yang dipersepsikan produk atau hasil terhadap ekspektasi mereka. Jika kinerja gagal memenuhi ekspektasi, pelanggan akan tidak puas, jika kinerja sesuai ekspektasi, pelanggan akan puas, jika kinerja melebihi ekspektasi, pelanggan akan sangat puas atau senang (Kotler, 2015). Tujuan Penelitian ini adalah mengetahui tingkat kepuasan kepuasan pasien rawat inap dan rawat jalan di Rumah Sakit MH.Thamrin Cilengsi., Mengidentifikasi karakteristik pasien rawat inap dan rawat jalan serta mempelajari dan menganalisis hubungan karakteristik pasien di RS MH Thamrin Cilengsi. Dengan Penentuan Prioritas Perbaikan Mutu Pelayanan menggunakan digram kartesius.Desain penelitian cross sectional dengan metode pengumpulan sampel yang dilakukan pada penelitian ini adalah convinience sampling,jumlah sample pada penelitianini adalah 388 responden, terdiri dari pasien rawat inap140 responden dan rawat jalan 248 responden. Ditemukan 71,4\% responden merasa puas akan pelayanan rawat inap dan $80,6 \%$ pasien merasa puas akan pelayanan rawat jalan. Terdapat hubungan antara pekerjaan dengan kepuasan pasien rawat inap. Prioritas perbaikan mutu pelayanan rawat inap di RS. MH. Thamrin Cileungsi adalah kenyamanan dan kebersihan ruangan. Sedangkan prioritas perbaikan rawat jalan adalah komponen kompetensi dan pelayanan yg diberikan oleh dokter dan keberadaan petugas Apotik dan lamanya pasien menunggu obat.
\end{abstract}

Kata Kunci: Kepuasan Pasien, Rawat Inap, Rawat Jalan

\section{PENDAHULUAN}

Setiap rumah sakit dituntut untuk mewujudkan pelayanan yang efisien, efektif dan bermutu secara paripurna serta berorientasi pada kepuasan pasien. Adapun salah satu upaya yang dapat dilakukan demi memenangkan persaingan ini adalah dengan memberikan pelayanan yang berkualitas melalui peningkatan sarana, fasilitas serta sumber daya manusia (Wiyono dkk, 2006). Pelayanan kesehatan yang bermutu menurut Azwar (1996) adalah pelayanan kesehatan yang dapat memuaskan setiap pemakai jasa pelayanan sesuai dengan tingkat kepuasan rata-rata penduduk serta penyelenggaraannya sesuai dengan kode etik dan standar pelayanan yang telah ditetapkan.

Gerakan revolusi mutu melalui pendekatan manajemen mutu terpadu menjadi tuntutan yang tidak boleh diabaikan jika suatu lembaga ingin hidup dan berkembang. Persaingan yang semakin ketat akhir-akhir ini menuntut sebuah lembaga penyedia jasa atau layanan untuk selalu memanjakan pelanggan (konsumen) dengan memberikan pelayanan terbaik. Para konsumen akan mencari produk berupa barang atau jasa dari perusahaan yang dapat memberikan pelayanan yang terbaik kepadanya (Assauri, 2003: 25). Masalah utama sebagai sebuah lembaga jasa pelayanan kesehatan adalah semakin banyaknya pesaing. Oleh karena itu, rumah sakit dituntut untuk selalu menjaga kepercayaan konsumen dengan meningkatkan kualitas pelayanan agar kepuasan konsumennya meningkat. Pihak rumah sakit perlu secara cermat menentukan kebutuhan konsumen sebagai upaya untuk memenuhi keinginan dan meningkatkan kepuasan atas pelayanan yang diberikan (John, J., 1992: 57).

Pada umumnya pasien yang merasa tidak puas akan mengajukan komplain pada pihak rumah sakit. Komplain yang tidak segera ditangani akan mengakibatkan menurunnya kepuasan pasien terhadap kapabilitas pelayanan 
kesehatan di rumah sakit tersebut. Kepuasan konsumen telah menjadi konsep sentral dalam wacana bisnis dan manajemen. Konsumen umumnya mengharapkan produk berupa barang atau jasa yang dikonsumsi dapat diterima dan dinikmatinya dengan pelayanan yang baik atau memuaskan (Assauri, 2003: 28). Pasien dikatakan puas jika pelayanan yang diterima oleh pasien sesuai dengan harapan pasien atau melampaui harapan yang pasien inginkan dan jika pelayanan yang diterima oleh pasien tidak sesuai harapan maka sebaliknya pasien tidak puas (Ehsan, et al, $2014: 2$ ). Tingkat kepuasan pasien akan berpengaruh terhadap kunjungan ulang. Studi yang dilakukan oleh Prastiwi dan Ayubi (2008) menunjukkan bahwa pasien yang merasa puas terhadap pelayanan fasilitas kesehatan memiliki peluang 7,5 kali lebih besar untuk melakukan kunjungan ulang dibandingkan dengan pasien yang merasa tidak puas.

Menurut hasil penelitian Laksono (2008) jumlah persentase pendapatan rawat terhadap total pendapatan rumah sakit di Brebes pada tahun 2007 menurun sebesar 43\% jika dibandingkan dengan persentase pendapatan rawat inap pada tahun 2006. Angka kunjungan pasien lama rawat inap sangat kecil bila dibandingkan dengan angka kunjungan pasien lama rawat jalan, hal tersebut diakibatkan karena ketidakpuasan pasien terhadap pelayanan yang diberikan oleh pihak rumah sakit. Menurut Leboeuf, penurunan jumlah kunjungan pelanggan lama disebabkan; 3\% karena pindah tempat tinggal, 5\% karena menemukan persahabatan baru di perusahaan lain, 9\% karena bujukan pesaing, 14\% karena merasa tidak puas, dan 68\% karena sikap masa bodoh atau tidak perhatian yang diperlihatkan oleh pemilik, manajer atau karyawan. Upaya untuk menarik pelanggan yang baru rata-rata perusahaan menghabiskan waktu enam kali lebih banyak daripada waktu yang dipakainya untuk mempertahankan pelanggan lama. Padahal dalam sebagian besar kasus, loyalitas pelanggan mempunyai nilai 10 kali lebih besar daripada uang yang dibelanjakannya dalam satu kali pembelian. Kemampuan rumah sakit dalam memenuhi kebutuhan pasien dapat diukur dari tingkat kepuasan pasien. Dalam penelitian kepuasan pasien ini akan dilakukan melalui pendekatan Lima Dimensi yang dikemukakan oleh Parasuraman. Kelipa dimensi itu adalah: Tangibles (Wujud), Relability (Kehandalan), Responsiveness (DayaTanggap), Assurance (Jaminan), Empathy (Empati).

\section{METODE}

Rancangan penelitian yang akan dilakukan adalah rancangan survei. Rancangan survei dilakukan untuk mendapatkan gambaran kepuasan pasien terhadap pelayanan RS MH. Thamrin Cileungsi. Populasi pada penelitian ini adalah seluruh pasien yang memanfaatkan pelayanan kesehatan di RS. MH. Thamrin Cileungsi pada bulan Agustus-September 2016. Rumah Sakit MH. Thamrin Cileungsi terdiri dari unit rawat jalan dan rawat inap. Sampel pada penelitian ini adalah pasien terpilih yang sesuai dengan kriteria inklusi yang telah ditetapkan. Adapun kriteria insklusi yang digunakan adalah pasien dewasa (20 tahun keatas) yang rawat inap di RS MH. Thamrin Cileungsi, suda dirawat minimal 2 hari. Untuk pasien yang sakit berat, digunakan proxy responden, yaitu keluarga penunggu pasien.

Metode pengumpulan sampel yang dilakukan pada penelitian ini adalah convinience sampling, yaitu sampel diambil pada individu yang mudah ditemui. Hal ini dilakukan karena random sampling tidak dapat dilakukan mengingat sulitnya mendapatkan sampling frame. Hal ini disebabkan karena jumlah pasien yang berobat di RS MH Thamrin Cileungsi berubah-berubah setiap bulannya. Instrumen pengumpulan data dikembangkan oleh 
peneliti berdasarkan kajian literatur. Pada studi ini diperoleh bahwa kuesioner kepuasaan pasien akan ditanyakan berdasarkan lima elemen pembentuk kepuasan, yaitu elemen tangibles, reliability, responsiveness, assurance dan emphaty. Penentuan Prioritas Perbaikan Mutu Pelayanan, untuk menentukan urutan prioritas pembenahan mutu pelayanan dilakukan dengan cara membuat Diagram Kartesius yang berfungsi untuk memetakan nilai skor rata-rata kinerja. Sumbu datar $(\mathrm{X})$ diisi oleh skor tingkat persepsi / kenyataan pasien, sedangkan sumbu tegak (Y) diisi oleh skor tingkat kepentingan/harapan pasien, Supranto (2006)

\section{HASIL}

Gambaran kepuasan pasien rawat inap dan rawat jalan di Rumah Sakit MH. adalah pengakuan dari responden yang telah menggunakan Rumah Sakit MH. Thamrin Cileungsi sebagai fasilitas kesehatan selama responden dirawat maupun pelayanan rawat jalan. Dengan menganalisa antara kenyataan dan harapan dari masing masing komponen dari pasien rawat inap yang terdiri dari Tangibility ( bukti fisik), reliability (kehandalan) Responsiviness ( daya tanggap), assurance ( jaminan) dan Emphaty (perhatian). Sedangkan untuk rawat jalan adalah dengan mengalisis harapan dan kenyataan dari masing masing komponon yang ada di pelayanan rawat jalan rumah Sakit MH. Thamrin Cileungsi yaitu pelayanan yang diberikan oleh Admission ( rekam medis), perawat, dokter, laboratorium, apotik dan kasir. Dari hasil survey diperoleh 71,4\% pasien menyatakan puas terhadap pelayanan rawat inap dan $25,4 \%$ tidak puas atas pelayanan rawat inap di RS.MH. Thamrin Cileungsi. Bila diliahat dari dimensi kepuasan dihasilkan bahwa pada dimensi tangibility 82,1\% pasien merasa puas, dimensi Reliability $91,4 \%$ merasa puas, responsiveness $97,1 \%$ merasa puas, assurance $94,3 \%$ dan emphaty $85,7 \%$ pasien merasa puas.

Gambaran responden berdasarakan karakteristik pasien di rumah sakit MH. Thamrin Cileungsi. Dilihat dari karakteristik pasien yang dirawat inap di rumah Sakit MH. Thamrin Cileungsi, distribusi karaktersitik responden menunjukkan sebanyak 92,1\% usia dewasa ( $<60$ th), sebanyak 58,6\% perempuan, sebagian besar responden berpendidikan tinggi ( $\geq$ SMA) sebanyak $80,7 \%$ dan $19,3 \%$ berpendidikan rendah ( $\leq$ SMP). Untuk pekerjaan Responden sebagain responden tidak bekerja 52,9 \% dan bekerja 47,1\%. Sumber biaya responden sebagian besar responden biaya BPJS/Askes/KIS/KJS sebanyak 87,1\% dan $12,9 \%$ Non BPJS/Askes/KIS/KJS. Sedangkan untuk ruang perawatan terbanyak di ruang kelas 2 yaitu $43,6 \%$ dan yang terkecil di Ruang Perawatan VIP sebanyak 2,9\%.

Analisis Penentuan Prioritas Perbaikan Mutu, dapat dilihat bahwa sebaran responden terhadap dimensi Tangibility berada di kuadran A, C dan D. Kuadran A adalah unsur - unsur data yang sangat penting bagi pasien/pelanggan rawat inap, akan tetapi pihak Rumah Sakit belum melaksanakan sesuai dengan keinginan pasien, sehingga menimbulkan kekecewaan rasa tidak puas. Adapun unsur- unsur yang terdapat di kuadran A adalah Kenyamanan ruang perawatan, kebersihan kamar perawatan dan kamar mandi, Tempat parkir dirumah sakit. Sedangkan kuadran $\mathrm{C}$ adalah unsur - unsur yang memang dianggap kurang penting oleh pasien/pelanggan rawat inap dimana sebaiknya Rumah Sakit menjalankan secara sedang saja. Adapun unsur yang berada dikuadran $\mathrm{C}$ adalah kenyamanan ruang tunggu yang disiapkan. Kuadran D adalah unsur- unsur jasa yang dianggap kurang penting, tetapi telah dijalankan dengan baik oleh Rumah Sakit sangat memuaskan. Adapun unsur - unsur yang terdapat di kuadran D adalah Kerapihan dan kebersihan lingkungan rumah sakit dan ruang 
rawat inap, Penerangan lampu dan bangsal dan halaman rumah sakit yang sudah baik, Kelengkapan peralatan medis, Kerapihan berpakaian perawat/bidan, Kelengkapan pelayanan laboratorium, Peralatan makan bersih dan kondisinya baik dan Kerapihan dokter dalam berpakaian.

Dimensi reliability, dapat dilihat bahwa sebaran responden berada pada kuadran A, B dan D. Adapun unsurunsur yang terdapat di kuadran A adalah, Ketelitian dokter dalam memeriksa pasien, Dokter memberikan informasi tentang penyakit dengan jelas, Menu makanan bervariasi. Kuadran B adalah unsur- unsur jasa pokokyang dianggap penting oleh pasien/pelanggan rawat inap telah dilaksanakan dengan baik dan dapat memuaskan pelanggan, maka ini kewajiban dari rumah sakit untuk mempertahankan kinerjanya. Adapun unsurunsur yang terdapat pada kuadran B adalah Perawat /bidan memberikan informasi dengan jelas sebelum tindakan, Apotik/farmasi melayani dengan cepat. Kuadran D adalah Makanan yang diberikan tepat waktu, Perawat/bidan profesional dalam menjalankan tugas, Petugas memberikan pelayanan dengan sungguh- sungguh. Dimensi responsiveness (daya tanggap) terdapat pada kuadran A dan D, yaitu Komponen yang berada dikuadran A adalah, Kesopanan dan keramahan perawat/bidan terhadap pasien, kecepatan tanggapan dokter saat diperlukan, kesoponan dan keramahan peraat/bidan terhadap keluarga pasien. Dan kuadran D adalah komponen keramahan dokter terhadap pasien, dokter mudah untuk dihubungi, tanggapan dari bidan/perawat cepat saat diperlukan dan Petugas selalu bersedia membantu.

Dimensi assurance (jaminan ) pelayanan rawat inap di RS. MH. Thamrin Cileungi. Tersebar pada kuadran A dan D. Dimana komponen yang terdapat dikuadran A adalah Petugas administrasi teliti dan menguasai pekerjaan dengan baik, Petugas administrasi menjelaskan hak dan kewajiban pasien, Petugas pendaftaran memberikan informasi dengan jelas. Dan komponen yang terdapat pada kuadran D adalah Kenyamanan pasien selama dirawat dirumah sakit, petugas trampil dalam memberikan pelayanan

petugas yang memberikan pelayanan sesuai dengan keahliannya.

Dimensi Emphaty rawat inap di RS. MH. Thamrin Cileungsi adalah Tersebar pada kuadran A dan D. komponen yang terdapat pada kuadran A adalah Keluarga dapat menjenguk pasien setiap waktu dan keluarga tidak dibatasi untuk menjenguk pasien. Sedangkan komponen yang terdapat padakuadran D adalah Petugas memberikan dorongan /semangat kepada pasiensupaya cepat sembuh, petugas tidak membeda-bedakan aantar pasien, Pelayanan tidak berbelit- belit, peraturan mengenai prosedur keuangan sebelum masuk ruang perawatan mempermudah pasien. Secara keseluruhan kepuasan pasien terhadap pelayanan rawat inap di RS. MH. Thamrin Cileungsi tersebar keseruruh kuadran.

Hubungan karakteristik pasien dan kepuasan pasien di rawat inap RS. MH. Thamrin Cileungsi sebagian besar responden menyatakan puas dengan pelayanan rapat inap yang diberikan di rumah sakit $\mathrm{MH}$. Thamrin Cileungsi pada aspek tangibility. Hubungan antara pekerjaan dengan dimensi kepuasan tangibility (bukti fisik) dengan nilai $\mathrm{p}$ Value $0,037(\mathrm{p}<\alpha)$. Kesimpulan uji menunjukkan adanya hubungan antara pekerjaan dengan tingkat kepuasan pasien pada dimensi tangibility. Dari hasil uji juga menunjukan nilai OR 2.862 yang artinya responden yang tidak bekerja berpeluang merasa puas pada a spek tangibility sebanyak 2.862 kali dibanding responden yang bekerja. Sebagain besar responden menyatakan puas terhadap dimensi reliability ( kehandalan). Hasil uji statistik menunjukan semua nilai $\mathrm{p}<\alpha$, maka dapat disimpulkan tidak ada hubungan antara aspek umur, jenis kelamin, tingkat pendidikan,pekerjaan, sumber biaya dan kelas perawatan dengan kepuasan pada 
dimensi reliability. Sebagain besar responden menyatakan puas terhadap dimensi responsiveness.. Hasil uji statistik menunjukan semua nilai $\mathrm{p}<\alpha$, maka dapat disimpulkan tidak ada hubungan antara aspek umur, jenis kelamin, tingkat pendidikan, pekerjaan, sumber biaya dan kelas perawatan dengan kepuasan pada dimensi responsiveness. Sebagain besar responden menyatakan puas terhadap dimensi assurance (kehandalan). Hasil uji statistik menunjukan semua nilai $\mathrm{p}<\alpha$, maka dapat disimpulkan tidak ada hubungan antara aspek umur, jenis kelamin, tingkat pendidikan, pekerjaan, sumber biaya dan kelas perawatan dengan kepuasan pada dimensi assurance. Sebagain besar responden menyatakan puas terhadap dimensi empathy. Hasil uji statistik menunjukan semua nilai $\mathrm{p}<\alpha$, maka dapat disimpulkan tidak ada hubungan antara aspek umur, jenis kelamn, tingkat pendidikan, pekerjaan, sumber biaya dan kelas perwatan dengan kepuasan pada dimensi emphaty.

Gambaran kepuasan pasien rawat jalan di Rumah Sakit MH. Thamrin Cileungsi, kepuasan pasien terhadap pelayanan kesehahatan rawat jalan di rumah sakit MH. Thamrin cileungsi, sebagian besar pasien merasa puas pada pelayanan admission $84,5 \%$, perawat $85,5 \%$ dan dokter $83,5 \%$. Sedangkan dengan pelayanan laboratorium hanya 28,2 \% yang menggunakan pelayanan laboratorium 6,0\% menyatakan tidak puas. Dan hanya 4,8\% yang menggunakan pelayanan kasir $0,8 \%$ menyatakan tidak puas. Total kepuasan rawat jalan 80,6 $\%$ pasien puas akan pelayanan rawat Jalan di rumah Sakit MH. Thamrin Cileungsi.

Gambaran responden berdasarakan karakteristik pasien Rawat Jalan di rumah sakit MH. Thamrin Cileungsi. Dilihat dari karakteristik pasien yang Rawat jalan di rumah Sakit MH. Thamrin Cileungsi umur responden 88,3 $\%$ usia dewasa , responden laki - laki sebanding dengan perempuan, sebagian besar tingkat pendidikan responden tinggi $76,2 \%$, pekerjaan responden sebanding antara yang bekerja ( 51,8 \%) dan tidak bekerja $(48,4 \%)$ sumber pembiayaan $88,7 \%$ responden adalah BPJS.

Analisis Penentuan Prioritas Perbaikan Mutu rawat jalan di rumah Sakit MH. Thamrin Cileungsi, sebaran kepuasan responden pada playanan rekam medis berada pada kuadran B dan D. Dimana komponen yang terdapat dalam kuadran B adalah Ruang pendaftaran dalam keadaan bersih, bagian pendaftaran melayani dengan cepat sedangkan komponen yang terdapat pd kuadran D adalah Ketepatan waktu buka loket pendaftaran, Jadwal buka/tutup loket pendaftaran diinformasikan dengan jelas, Petugas pendaftaran mengarahkan ke poliklinik, ruang tunggu dalam keadaan bersih.

Sebaran Kepuasan pasien terhadap pelayanan perawat di rawat jalan RS. MH. Thamrin Cileungsi dikuadran A, B dan D, dimana komonon yang terdapat pada kuadran A adalah Perawat datang sesuai dengan jadwal/tidak terlambat, perawat dalam memberikan pelayanan menumbuhkan semangat dan kepercayaan pasien, perawat yang melayani sesuai dengan kompetensinya, perawat menjawab dengan baik dan ramah jika ditanya. Komponen yang terdapat pada kuadranB adalah pasien merasa aman menerima pelayanan perawat. Dan komponen yang terdapat pada kuadran D adalah Perawat

Sebaran responden terhadap pelayanan dokter berada di kuadran B, C dan D rampil dalam merawat/memberikan tindakan yang tepat kepada pasien. Komponen yang terdapat pada kuadran B adalah Jadwal kedatangan dokter di poliklinik dilaksanakan sesuai jadwal, dokter berbicara dengan pasien tentang proses pengobatan yang didapatkan, dokter selalua dadi ruangan pemeriksaan saat jam pelayanan, dokter yang ada sesuai dengan jadwal dokter yang seharusnya bertugas saat itu, dokter yang melayanis esuai dengan kompetensinya, dokter dalam memberikan pelayanan mampu menumbuh kan semangat dan kepercayaan pasien. 
Sedangkan komponen yang terdapat pada kuadran C adalah Dokter trampil dalam memberikan tindakan yang tepat kepada pasien dan Pasien merasa aman dengan pelayanan yang diberikan oleh dokter. Sedangkan komponen yang terdapat pada kuadran D adalah Tindakan dokter bebas dari bahaya, resiko dan keragu-raguan dan kerahasiaan pemeriksaan pasien terjaga oleh dokter.

Sebaran kepuasan dan harapan pasien terhadap pelayanan laboratorium di rumah Sakit MH. Thamrin Cileungsi sebaran pelayanan berada di kuadran antara Adan B, kuadran B dan Kuadran C. Komponen yang berada diantara kuadran A dan B adalah . Komponen yang terdapat pada kuadran A dan B adalah, jadwal buka tutup laboratorium/radiologi diinformasikan dengan jelas, jadwal buka/tutup laboratorium/radiologi diinformasikan dengan jelas, petugas memberikan penjelasan yang cukup tentana pemeriksaanpetugas laboratorium/radiologi tidak pernah salah/ mengulang ketika mengambil sampel/foto. Komponen yang terdapatpada kuadran B adalah Petugas laboratorium/radiologi terampil ketika melayani pasien, Petugas laboratorium/radiologi sopan dan ramah ketika melayani pasien. Sedamgkan komponen yang terdapat pada kuadran C adalah: petugas laboratorium selalu menggunakan jarum yang baru ketika mengambil darah dan cara yang digunakan steril.

Sebaran kepuasan pasien pada pelayanan apotik tersebar pada kuadran A, C dan D. Komponen yang terdapat pada kuadran A adalah : jadwal buka /tutup diinformasikan dengan jelas. Adapun unsur- unsur yang terdapat pada kuadran $\mathrm{C}$ adalah: petugas apotik selalu ada di apotik.Serta Unsur yang terdapat pada kuadran D adalah jadwal buka/tutup apotik diinformasikan dengan jelas, ketepatan pemberian obat, ketersediaanobat diapotik/obat selalu ada, petugas apotik menjelaskan cara pemakaian obat, kemudahan pelayanan di apotik dan obat yang pasien dapatkan dari apotik bebas dan tidak ada yang kadaluarsa.

Sebaran responden terhadap pelayanan kasir dikuadran A,B dan D, unsur - unsur yang terdapat dikuadran A adalah : Rincian pembayaran pasien jelas. Unsur yang terdapat pada kuadran B adalah biaya yang pasien bayar sesuai dengan pelayanan yang pasien terima. Unusr yang terdapat pada kuadran D adalah Tarif pelayanan diinformasikan dengan baik, biaya yang pasien bayar sesuai dengan tarif yang berlaku, petugas kasir dan petugas lainnya terampil ketika melayani pasien, Petugas kasir dan petugas lainnya sopan dan ramah ketika melayani pasien.

Kepuasan responden dengan seluruh komponen pelayanan rawat jalan di rumah Sakit MH. Thamrin Cileungsi tersebar pada kuadran A, B dan C. Unusr yang terdapat pada kuadran A adalah Ketrampilan Dokter dalam memberikan tindakan yang tepat pada pasien, rasa aman pasien dalam menerima pelayanan dokter, kejelasan informasi jadwal buka/ tutup apotik, kesesuaian Jadwal buka/tutup apotik dengan jadwal, keberadaan petugas Apotik, waktu lamanya pasien menunggu obatnya, obet tersediaan obat diapotik/obat selalu ada, ketepatan pemberian obat, ketersediaan obat di apotik dan kesopanan dan keramahan petugas ketika melayani pasien. Sedangkan unsur yang terdapat pada kuadran B adalah Kecepatan bagian pendaftaran melayani pasien, ketepatan waktu buka loket pendaftaran, kejelasan informasi jadwal buka/tutup pendaftaran, kecukupan jumlah tempat duduk di ruang tunggu, kebersihan dan kerapihan toilet, kebersihan ruang pendaftaran, kebersihan ruang tunggu, jumlah tempat duduk di ruang tunggu mencukupi, jadwal waktu buka poliklinik sesuai jadwal, perawat datang sesuai dengan jadwal/tidak terlambat, perawat dalam memberikan pelayanan menumbuhkan semangat dan kepercayaan pasien, perawat yang melayani sesuai dengan kompetensinya, perawat menjawab dengan baik dan ramah saat ditanya. Dan unsur yang terdapat pada kuadran $\mathrm{C}$ adalah Kejelasan informasi jadwal buka/tutup 
laboratorium/radiologi, kesesuaian jadwal buka/tutup laboratorium/radiologi dengan jadwalnya, pemberian penjelasan yang cukup tentang pemeriksaan oleh petugas, petugas laboratorium/radiologi sopan dan ramah ketika melayani pasien, petugas laboratorium/radiologi trampil dalam melayani pasien, petugas laboatorium/radiologi tidakpernah salah/mengulang ketika mengambil sampel/foto, tarif pelayanan di informasikan dengan jelas, biaya yang pasien bayar sesuai dengan tarif yang berlaku, biaya yang pasien bayar sesuai dengan pelayanan yang diterima, rincian pembayaran pasien jelas, petugas kasir/lainnya terampil ketika melayani pasien, petugas kasir/lainnya ramah dan sopan ketika melayani pasien, Jumlah uang kembali tidak pernah kurang.

Hubungan karakteristik pasien dan kepuasan pasien di rawat jalan RS. MH. Thamrin Cileungsi hubungan antara umur responden dengan kepuasan pelayanan admission diperoleh bahwa ada sebanyak $189(86,7 \%)$ responden yang usia dewasa merasa puas akan palayanan admission. Sedangkan diantara respnden yang berusia kategori lansia ada $20(74,1 \%)$ responden yang merasa puas. Hubungan jenis kelamian dengan kepuasan diperoleh bahwa ada $100(82,6)$ responden laki- laki puas, sedangkan responden perempuan ada $109(87,9 \%)$ merasa puas. Hubungan Tingkat pendidikan dengan kepuasan diperoleh bahwa ada 49 ( 83,1\%) responden yang berpendidikan rendah puas akan pelayanan admission. Sedangkan responden yang berpendidikan tinggi sebanyak $161(86,1 \%)$ merasa puas, hubungan pekerjaan dengan kepuasan, terdapat $110(86,6 \%)$ responden yang puas sedangkan diantara responden yang tidak bekerja ada $100(84 \%)$ yang puas akan pelayanan admission. Hasil analisis hubungan sumber biaya dengan kepuasan, sebanyak 20 (74,1 \%) responden yang tidak menggunakan BPJS puas akan pelayanan admission, sedangkan ada 190 (86,9 \%) pasien yang menggunakan BPJS/Askes/KIS merasa puas akan pelayanan admission. Uji statistik menunjukan semua nilai $\mathrm{p}$ $<\alpha$, maka dapat disimpulkan tidak ada hubungan antara aspek umur, jenis kelamn, tingkat pendidikan, pekerjaan, sumber biaya dengan kepuasan pada pelayanan admission.

Hubungan antara umur responden dengan kepuasan pelayanan perawat diperoleh bahwa ada sebanyak 191 $(86,2 \%)$ responden yang usia dewasa merasa puas akan palayanan perawat. Sedangkan diantara responden yang berusia kategori lansia ada $20(71,4 \%)$ responden yang merasa puas. Hubungan antara jenis kelamian dengan kepuasan diperoleh bahwa ada $99(81,1 \%)$ responden laki- laki puas, sedangkan responden perempuan ada $112(89,6 \%)$ merasa puas. Hubungan antara tingkat pendidikan dengan kepuasan diperoleh bahwa ada 49 ( $83,1 \%$ ) responden yang berpendidikan rendah puas akan pelayanan perawat. Sedangkan responden yang berpendidkan tinggi sebanyak $163(86,2 \%)$ merasa puas.

Hubungan pekerjaan dengan kepuasan, terdapat 111 (86,7\%) responden yang puas sedangkan diantara responden yang tidak bekerja ada $110(86,4 \%)$ yang puas akan pelayanan perawat. Hubungan sumber biaya dengan kepuasan, sebanyak $20(71,4 \%)$ responden yang tidak menggunakan BPJS puas akan pelayanan perawat, sedangkan ada $192(87,3 \%)$ pasien yang menggunakan BPJS/Askes/KIS merasa puas akan pelayanan dokter. Uji statistik menunjukan semua nilai $\mathrm{p}<\alpha$, maka dapat disimpulkan tidak ada hubungan antara aspek umur, jenis kelamn, tingkat pendidikan, pekerjaan, sumber biaya dengan kepuasan pada pelayanan perawat.

Hubungan antara umur responden dengan kepuasan pelayanan dokter diperoleh bahwa ada sebanyak 187 $(91,2 \%)$ responden yang usia dewasa merasa puas akan palayanan dokter. Sedangkan diantara responden yang berusia kategori lansia ada $19(79,2, \%)$ responden yang merasa puas. Hubungan antara jenis kelamian 
dengan kepuasan diperoleh bahwa ada 100 (88,5\%) responden laki - laki puas, sedangkan responden perempuan ada $106(91,4 \%)$ merasa puas, hubungan antara tingkat pendidikan dengan kepuasan diperoleh bahwa ada 46 (90,4\%) responden yang berpendidikan rendah puas akan pelayanan dokter. Sedangkan responden yang berpendidkan tinggi sebanyak 160( 86,2\%) merasa puas. Hubungan pekerjaan dengan kepuasan , terdapat $111(86,7 \%)$ responden yang puas sedangkan diantara responden yang tidak bekerja ada $110(86,4 \%)$ yang puas akan pelayanan dokter. Hubungan sumber biaya dengan kepuasan, sebanyak $20(71,4 \%)$ responden yang tidak menggunakan BPJS puas akan pelayanan dokter, sedangkan ada 192 (87,3\%) pasien yang menggunakan BPJS/Askes/KIS merasa puas akan pelayanan dokter. Uji statistik menunjukan semua nilai $\mathrm{p}<\alpha$, maka dapat disimpulkan tidak ada hubungan antara aspek umur, jenis kelamn, tingkat pendidikan, pekerjaan, sumber biaya dengan kepuasan pada pelayanan dokter.

Hubungan antara umur responden dengan kepuasan pelayanan laboratorium diperoleh bahwa ada 45 (80,4\%) responden yang usia dewasa merasa puas akan palayanan laboratorium. Sedangkan diantara responden yang berusia kategori lansia ada $9(69,2 \%)$ responden yang merasa puas . Hubungan antara jenis kelamian dengan kepuasan diperoleh bahwa ada $26(72,2 \%)$ responden nlaki - laki yang puas, sedangkan responden perempuan ada 29 (85,3\%) merasa puas. Hubungan antara tingkat pendidikan dengan kepuasan diperoleh bahwa ada 16 $(76,2 \%)$ responden yang berpendidikan rendah puas akan pelayanan laboratorium. Sedangkan responden yang berpendidkan tinggi sebanyak 39(79,6\%) .

Hubungan pekerjaan dengan kepuasan, terdapat $30(83,3 \%)$ responden yang puas sedangkan diantara responden yang tidak bekerja ada 25 (73,5\%) yang puas akan pelayanan laboratorium, hubungan sumber biaya dengan kepuasan, sebanyak $6(54,5 \%)$ responden yang tidak menggunakan BPJS puas akan pelayanan laboratorium, sedangkan ada $49(83,1 \%)$ pasien yang menggunakan BPJS/Askes/KIS merasa puas akan pelayanan laboratorium. Uji statistik menunjukan semua nilai $\mathrm{p}<\alpha$, maka dapat disimpulkan tidak ada hubungan antara aspek umur, jenis kelamn, tingkat pendidikan, pekerjaan, sumber biaya dengan kepuasan pada pelayanan laboratorium.

Hubungan antara umur responden dengan kepuasan pelayanan apotik diperoleh bahwa ada 190 (87,2\%) responden yang usia dewasa merasa puas akan palayanan laboratorium, sedangkan diantara responden yang berusia kategori lansia ada 20 (71,4\%). hubungan antara jenis kelamian dengan kepuasan diperoleh bahwa ada $101(83,5 \%)$ responden laki- laki merasa puas, sedangkan responden perempuan ada 109 (87,2\%). Hubungan antara tingkat pendidikan dengan kepuasan diperoleh bahwa ada $49(83,1 \%)$ responden yang berpendidikan rendah puas akan pelayanan apotik. Sedangkan responden yang berpendidkan tinggi sebanyak $162(86,2 \%)$. Hubungan pekerjaan dengan kepuasan, terdapat 112 (88,2\%) responden yang puas sedangkan diantara responden yang tidak bekerja ada 99 (82,5\%). Hubungan sumber biaya dengan kepuasan, sebanyak 20 $(71,4 \%)$ responden yang tidak menggunakan BPJS puas akan pelayanan apotik, sedangkan ada $191(87,2 \%)$ pasien yang menggunakan BPJS/Askes/KIS merasa puas akan pelayanan apotik. Uji statistik menunjukan semua nilai $\mathrm{p}<\alpha$, maka dapat disimpulkan tidak ada hubungan antara aspek umur, jenis kelamin, tingkat pendidikan, pekerjaan, sumber biaya dengan kepuasan pada pelayanan apotik. Hubungan antara umur responden dengan kepuasan pelayanan kasir diperoleh bahwa ada $10(83,3 \%)$ responden yang berusia kategori deawasa merasa puas. Hubungan antara jenis kelamian dengan kepuasan diperoleh bahwa ada 3 (100\%) 
responden laki- laki merasa puas puas, sedangkan responden perempuan ada 7 (77,8\%) merasa puas. Hubungan antara tingkat pendidikan dengan kepuasan diperoleh bahwa ada 1 ( $100 \%)$ responden yang berpendidikan rendah puas akan pelayanan apotik. Sedangkan responden yang berpendidkan tinggi sebanyak 9 ( $81,9 \%)$ merasa puas. Hubungan pekerjaan dengan kepuasan, terdapat $8(88,9 \%)$ responden yang puas sedangkan diantara responden yang tidak bekerja ada $2(66,7 \%)$ yang puas akan pelayanan kasir, hubungan sumber biaya dengan kepuasan, sebanyak $10(83,3 \%)$ responden yang non BPJS puas akan pelayanan kasir dan $2(16,7)$ pasien yang tidak puas dengan pelayanan kasir. Uji statistik menunjukan semua nilai $\mathrm{p}<\alpha$, maka dapat disimpulkan tidak ada hubungan antara aspek umur, jenis kelamin, tingkat pendidikan, pekerjaan, sumber biaya dengan kepuasan pada pelayanan kasir.

\section{PEMBAHASAN}

Pada penelitian ini Kepuasan pasein rawat inap RS.MH. Thamrin Cileungsi menunjukkan sebagai besar responden mengatakan puas pada dimensi reliability, dimensi responsiveness, dimensi assurance dan dimensi Empaty. Hasil penelitian ini sejalan dengan teori bahwa Tangible atau bukti langsung menurut Zoeldhan dalam Metayunika (2013) yaitu berupa bentuk pelayanan bukti fisik biasanya berupa sarana dan prasarana pelayanan yang tersedia, teknologi pelayanan yang digunakan, performance pemberi pelayanan yang sesuai dengan karakteristik pelayanan yang diberikan dalam menunjukkan prestasi kerja yang dapat diberikan dalam bentuk pelayanan fisik yang dapat dilihat. Bukti langsung atau tangible merupakan salah satu indikator yang sangat mempengaruhi bagaimana bentuk kualitas pelayanan bekerja untuk dapat memenuhi kepuasan konsumen.

Kehandalan (reliability) merupakan bentuk ciri khas atau karakteristik dari pegawai yang memiliki prestasi kerja tinggi. Kehandalan dalam pemberian pelayanan dapat terlihat dari kehandalan memberikan pelayanan sesuai dengan tingkat pengetahuan yang dimiliki, kehandalan dalam terampil menguasai bidang kerja yang diterapkan sesuai dengan skil yang mereka punya, kehandalan dalam penguasaan bidang kerja sesuai pengalaman kerja yang ditunjukkan dan kehandalan menggunakan teknologi kerja (Zoeldhan dalam Metayunika,2013).

Menurut Tjiptono dalam Metayunika (2013) daya tanggap ( responsiveness) yaitu keinginan para staf dan karyawan untuk membantu para pelanggan dan memberikan pelayanan dengan tanggap.Tanggap disini dapat diartikan bagaimana bentuk respon perusahaan terhadap segala hal-hal yang berhubungan dengan konsumen. Respon yang dimaksud sebaik-baiknya cara perusahaan dalam menerima entah itu permintaan, keluhan, saran, kritik, komplain, dan sebagainya atas produk atau bahkan pelayanan yang diterima oleh konsumen.

Assurance atau jaminan meliputi kemampuan karyawan atas pengetahuan terhadap produk secara tepat, kualitas keramahtamahan, perhatian, dan kesopanan member pelayanan, keterampilan dalam memberikan informasi, kemampuan dalam memberikan keamanan dalam memanfaatkan jasa yang ditawarkan, dan kemampuan dalam menanamkan kepercayaan pelanggan terhadap perusahaan (Zeithmal dalam Metayunika,2013). Empati dalam suatu pelayanan adalah adanya suatu perhatian, keseriusan, simpatik, pengertian dan keterlibatan pihak -pihak yang berkepentingan dengan pelayanan untuk mengembangkan dan melakukan aktivitas pelayanan sesuai dengan tingkat pengertian dan pemahaman dari masing-masing pihak tersebut. Empati membutuhkan adanya saling mengerti satu sama lain antara karyawan atau yang melayani dan yang dilayani atau konsumen agar 
tercipta suatu hubungan yang balance atau selaras dalam perusahaan tersebut. (Zoeldhan dalam Metayunika 2013).

Kepuasan pasein Rawat jalan, hampir semua pelayanan rawat jalan di RS. MH. Thamrin merasa puas. Hasil penelitian ini sejalan dengan teori bahwa Menurut Thoha (2002: 181) "kualitas pelayanan kepada masyarakat sangat tergantung pada individual aktor dan sistem yang dipakai". Dokter, perawat, dan tenaga penunjang medis serta non medis yang bertugas di rumah sakit harus memahami cara melayani konsumennya dengan baik terutama kepada pasien dan keluarga pasien, karena pasien dan keluarga pasien adalah konsumen utama di rumah sakit. Kemampuan rumah sakit dalam memenuhi kebutuhan pasien dapat diukur dari tingkat kepuasan pasien. Hal ini tentunya harus dipertahankan karena dengan kinerja yang baik maka akan terciptanya citra positif dan nama baik rumah sakit karena pasien yang puas tersebut akan memberitahukan kepuasannya kepada orang lain. Hal ini secara akumulatif akan menguntungkan rumah sakit karena merupakan pemasaran rumah sakit secara tidak langsung.

\section{KESIMPULAN DAN SARAN}

Kesimpulan Kepuasan pasien rawat inap di Rumah Sakit MH. Thamrin Cileungsi, untuk seluruh dimensi kepuasan (tangibility, reliability, responsiveness, assurance, emphaty) 71,4\% responden merasa puas akan pelayanan Rawat inap di RS. MH. Thamrin Cileungsi. Kepuasan pasien Rawat jalan di Rumah Sakit MH.Thamrin Cileungsi. Untuk Seluruh pelayanan yang diberikan (admission, perawat, dokter, laboratorium apotik dan kasir) 80,6\% pasien merasa puas. Terdapat hubungan antara karakteristik responden : pekerjaan terhadap kepuasan paien rawat inap di rumah sakit MH.Thamrin Cileungsi,. Penentuan Prioritas perbaikan mutu rawat inap terdapat pada Kuadran A Unsur-unsur yang dianggap penting ini harus mendapat prioritas untuk diperbaiki yaitu : Kenyamanan ruang perawatan, Kebersihan kamar perawatan dan kamar mandi dan Tempat parkir dirumah sakit Kenyamanan kamar perawatan, Petugas tidak membeda-bedakan antar pasien, Keluarga dapat menjenguk pasien tiap waktu, Keluarga tidak dibatasi untuk menunggu pasien. Penentuan Prioritas perbaikan mutu rawat jalan terdapat pada Kuadran A terdapat dikuadran A adalah : Keterampilan Dokter dalam memberikan tindakan yang tepat pada pasien, Rasa aman pasien dalam menerima pelayanan dokter, Kejelasan informasi jadwal buka/ tutup apotik, Kesesuaian Jadwal buka/tutup apotik dengan jadwal, Keberadaan petugas Apotik dan Waktu lamanya pasien menunggu obatnya. Saran untuk RS. MH.Thamrin Cileungsi adalah Perlu segera dilakukan perbaikan baik dari segi SDM dan fasilitas yang ada untuk meningkatkan mutu layanan baik rawat inap maupun rawat jalan. Karena tingkat kepuasan pasien baru mencapai $80 \%$. Perbaikan mutu RS. MH. Thamrin cileungsi segera dilakukan sesuai dengan prioritas yang harus diperbaiki baik untuk rawat inap maupun rawat jalan, karena beberapa unsur sangat penting bagi pasien, akan tetapi pihak rumah sakit belum melaksanakan sesuai dengan keinginan pasien, sehingga dapat menimbulkan kekecewaan dan rasa tidak puas pada pelanggan/pasien. 


\section{UCAPAN TERIMA KASIH}

1. Prof.Dr. Soekidjo Notoatmodjo, SKM.,M.Comm.H selaku rektor Universitas MH. Thamrin.

2. Dr. Ajeng Tias Endarti, SKM.,M.Comm.H selaku ketua LPPM Universitas MH. Thamrin

3. dr. Tiwi Handayani, selaku Direktur Rumah Sakit MH. Thamrin Cileungsi dan seluruh staf administrasi dan kepala divisi-divisi dirumah Sakit yang telah memberikan ijin dan memberikan saranadan prasarana yang ada.

\section{DAFTAR PUSTAKA}

1. Kotler, Philip Manajemen Pemasaran; Ed. XIII Jilid 1. Jakarta. 2015.

2. Wiyono, Azis. dkk.. Studi tentang kualitas pelayanan dan kepuasan konsumen di Rumah Sakit Islam Manis renggo Klaten, Tesis diterbitkan Program Pascasarjana Universitas Muhammadiyah Surakarta, 2006. ://blog.ub.ac.id/irbef/files/2012/05/AZIZ_SLAMET.pdf, diunduh pada tanggal 29 Juli 2016.

3. Azwar, A.Menjaga mutu pelayanan kesehatan.Yayasan Penerbit IDI. Jakarta, 1996

4. Assauri,S. Customer Service yang Baik Landasan Pencapaian Customer Satisfaction.Usahawan, No. 01, Tahun XXXII, Januari, hal.25-30: Jakarta. 2003.

5. John, J., Patient Satisfaction: The Impact of Past Experience. JHCM.Vol 12.No. 3.pp 56-64. 1992.

6. Prastiwi, E., Ayubi, D. Hubungan Kepuasan Pasien Bayar dengan Minat Kunjungan Ulang di Puskesmas Wisma Jaya Kota Bekasi Tahun 2007. Makara Kesehatan. 12 (1): 42-46 , 2008.

7. Leboeuf, M. Memenangkan dan Memelihara Pelanggan, Penerbit Pustaka Tangga, Jakarta, 1992.

8. Tjiptono, Fandy. Service Management Mewujudkan Pelayanan Prima. Penerbit Andi.Yogyakarta. . 2008

9. Tjiptono, Fandy. Service, Quality \& Satisfaction;Ed. IV. Yogyakarta: ANDI. 2016.

10. Wiyono, Azis. dkk.. Studi tentang kualitas pelayanan dan kepuasan konsumen di Rumah Sakit Islam Manis renggo Klaten, Tesis diterbitkan Program Pascasarjana Universitas Muhammadiyah Surakarta, 2006://blog.ub.ac.id/irbef/files/2012/05/AZIZ_SLAMET.pdf, diunduh pada tanggal 29 Juli 2016

11. Thoha, M. 2002. Perilaku Organisasi. Raja GrafindoPersada. Jakarta. 2002 